\title{
Seasonal abundance and sexual variation in morphometric traits of Oxelytrum discicolle (Brulle, 1840) (Coleoptera: Silphidae) in a Brazilian Atlantic Forest
}

\author{
Paulo Sérgio Fiuza Ferreira, ${ }^{1,2}$ Evaldo Martins Pires', Raul Narciso Carvalho Guedes', Márcio Mendes ${ }^{3}$ \& Lívia \\ Aguiar Coelho ${ }^{3}$
}

Biota Neotropica v6 (n2)-http://www.biotaneotropica.org.br/v6n2/pt/abstract?article+bn02206022006

\author{
Date Received 08/01/2005 \\ Revised 02/28/2006 \\ Accepted 05/11/2006
}
${ }^{1}$ Museu de Entomologia, Departamento de Biologia Animal, Universidade Federal de Viçosa, 36571-000 Viçosa, Minas Gerais, Brazil. 2Author Correspondent: (pfiuza@ufv.br)
${ }^{3}$ Museu de História Natural, Universidade do Vale do Rio Doce (UNIVALE), 35030-390 Governador Valadares, Minas Gerais, Brasil.

\begin{abstract}
Ferreira, P.S.F.; Pires, E.M.; Guedes, R;N.C.; Mendes, M. and Coelho, L.A. Seasonal abundance and sexual variation in morphometric traits of Oxelytrum discicolle (Brulle, 1840) (Coleoptera: Silphidae) in a Brazilian Atlantic Forest. Biota Neotrop. May/Aug 2006, vol. 6, no. 2, http://www.biotaneotropica.org.br/v6n2/pt/abstract?article+bn02206022006. ISSN 1676-0611
\end{abstract}

A total of 293 specimens of Oxelytrum discicolle were sampled weekly over a period of two years using a black light trap. The study took place in an Atlantic Forest reserve located near Viçosa city, Minas Gerais State, Brazil. The period of peak abundance of $O$. discicolle occurred during the wet season between the months of October and March. Statistical analysis showed that the abundance of individuals was significantly and positively correlated with temperature, but not with rainfall or relative humidity. Of 28 morphological measurements taken on each collected specimen, seven were found to be sexually dimorphic; however, neither morphology nor the degree of sexual dimorphism varied significantly among seasons.

Key words: Oxelytrum discicolle, population dynamic, sexual dimorphism, Minas Gerais

\section{Resumo}

Ferreira, P.S.F.; Pires, E.M.; Guedes, R;N.C.; Mendes, M. and Coelho, L.A. Abundância sazonal e variação morfométrica nos caracteres sexuais de Oxelytrum discicolle (Brulle, 1840) (Coleoptera: Silphidae) em uma floresta Atlântica brasileira. Biota Neotrop. Mai/Ago 2006, vol. 6, no. 2, http://www.biotaneotropica.org.br/v6n2/pt/abstract?article+bn02206022006. ISSN 1676-0611

Um total de 293 espécimes de Oxelytrum discicolle foram amostrados semanalmente num período de dois anos usando uma armadilha tipo “black light”. O estudo foi feito em uma reserva de Mata Atlântica localizada próximo à cidade de Viçosa, Minas Gerais, Brasil. O período de pico de abundância de O. discicolle ocorreu durante a estação úmida, entre os meses de outubro e março. A análise estatística mostrou que a abundância dos indivíduos foi significantemente e positivamente correlacionada com a temperatura, mas não com a precipitação e umidade relativa. De 28 características morfológicas tomadas em cada espécime coletado, sete foram encontradas sexualmente dimórficas, entretanto, nem morfologia nem o grau de dimorfismo sexual variaram significantemente entre as estações.

Palavras-chave: Oxelytrum discicolle, dinâmica populacional, dimorfismo sexual, Minas Gerais 


\section{Introduction}

The Silphidae (carrion beetles or burying beetles) are a distinct group living on dead vertebrate remains from the early decay to the late dry stage. There are conflicting descriptions of the food habits of silphids. Reed (1958) states that the immatures feed on the carrion and infrequently on maggots, while adults fed almost always on maggots. Payne and Crossley (1966) found adult silphids feeding only on maggots and did not mention immature food habits. Oliveira-Costa (2003) states silphids predators and Carvalho \& Linhares (2001) assert the carrion beetles are both predators and saprophagous.

The biological, systematic and ecological studies of carrion beetles of Brazil are very few. In a majority of papers the species of burying beetles are cited in inventories of collected insects. Outside Brazil, there is more information about silphid ecology (Anderson 1982, Wilson et al. 1984), physiology (Ements \& Zhulidov 1982, Wilson \& Knollenberg 1984), biology (Ements \& Zhulidov 1982, Peck \& Anderson 1982, Prins 1984) and systematic (Kryzhanouskii \& Sabiroba 1981, Schawaller 1977). According Costa (2000) the world fauna of carrion beetles is represented by 14 genera and 175 species. Neotropical Region has nine genera and 82 species. South America has six genera and 24 species, and one genus and three species in Brazil according Peck \& Anderson, (1982), and two genera and five species according Costa (2000). The major ecological role of the silphids is their living intimately with the decomposition process of vertebrate carcasses. Jointly with the flies and other beetles they are of major importance in studies of Forensic entomology (Catt \& Haskell 1990).

The objectives of this manuscript are to contribute to knowledge of Neotropical Silphidae in regard to the abundance of adults of Oxyelytrum discicolle under the influence of climate in dry and wet seasons; to evaluate if there are any morphological traits in different dry and wet seasons and between sex. Furthermore, the results will yield information for to researchers in Forensic entomology in Brazilian Atlantic Forest.

\section{Material and Methods}

The research took place on the natural reserve of Atlantic Forest set at municipality of Viçosa, State of Minas Gerais, Brazil, called Bacia do Córrego do Paraíso (coordinates: $20^{\circ} 45^{\prime} 16,5^{\prime \prime} \mathrm{S}$ and $42^{\circ} 51^{\prime}$ '53,2" W). The sample method employed a black light trap (Ferreira \& Martins 1982). The light trap was operated once a week during the period of 6:00 PM to 6:00 AM. The weather data were taken from Meteorological Station of Universidade Federal de Viçosa.

The sampling period was between August 1981 to July 1983. Specimens were identified at Identification Center for Fitophagous Insects (CIIF), Universidade Federal do Paraná (UFPR).
A total of 293 individuals of Oxelytrum discicolle was used in this study (170 female and 123 males).

The quantitative characters are based on measurements of 28 morphological features. They were made using an ocular micrometer Wild (10X) in a Wild M 5 microscope at various objective magnifications. The measurements of morphological structures were taken in millimeters and the values were computed for use in the general analysis. Figure 2 show exactly how the quantitative measurements were made: body length (Figure 2-1) = Ó head length, with length of the pronotum and elytron length, maximum body width (Figure 2-2), head length (Figure 2-3), head width (Figure 24 frons width (Figure 2-5), distance between antennal insection (Figure 2-6), length of the antennae (Figure 2-7), length of the antennal club (Figure 2-8), length of scape (Figure 2-9), length of $2^{\text {nd }}$ and $3^{\text {rd }}$ antennal segments (Figure 2-10), length of compound eye (Figure 2-11), width of compound eye (Figure 2-12), width of the pronotum base (Figure 2-13), median pronotum length (Figure 2-14), maximum pronotum width (Figure 2-15), scutellum length (Figure 2-16), width of the scutellum base (Figure 2-17), elytron length (Figure 2-18), maximum elytron width (Figure 2-19), length of the anterior femur (Figure 2-20), length of the anterior tibia (Figure 2-21), length of the anterior tarsi (Figure 2-22), length of the median femur (Figure 2-23), length of the median tibia (Figure 224), length of the median tarsi (Figure 2-25), length of the posterior femur (Figure 2-26), length of the posterior tibia (Figure 227), and length of the posterior tarsi (Figure 2-28).

Two statistical analyses were employed: correlation analysis (PROC CORRE: SAS Institute, 2001) and two-way multivariate analysis of variance using the procedure PROC GLM with the MANOVA statement from SAS (SAS Institute 2001).

The influence of the weather parameters of rainfall, temperature and relative humidity on the abundance of $O$. discicolle was tested using correlation analysis (PROC CORR; SAS Institute 2001). The full set of morphometric data was subjected to a two-way multivariate analysis of variance with season and sex as independent variables using the procedure PROC GLM with the MANOVA statement from SAS (SAS Institute 2001). Subsequent two-way univariate analyses of variance (PROC GLM; SAS Institute 2001) were carried out for each individual morphological trait complementing the multivariate analysis to recognize the traits that were indeed different between sex and/or season.

\section{Results}

A total of 293 specimens (170 females and 123 males) of Oxelytrum discicolle were collected throughout the sampling period (August 1981 to July 1983) and this species showed seasonal peaks of abundance during the wet season, between the months of October to March (Figure 1). However, there was no difference between the female/male rates ( $\pm 1.4: 1.0$, respectively). The abundance of this species was only significantly and positively correlated with 
temperature $(\mathrm{p}<0.05)$. This fact suggests the temperature as the main factor to the fly activities of $O$. discicolle (Table 1).

The two-way multivariate analysis of variance for the 28 morphometric traits assessed (Figure 2) indicated significant effect of sex $(p<0.05)$, while season showed only marginally significant effect $(p=0.05)$ (Table 2$)$. The interaction between sex and season was not significant (Table 2) and therefore was not further considered. The twoway univariate analyses of variance carried out for each individual trait indicated significant differences for seven morphological traits between the 28 assessed (Table 3). Among these seven traits, there were significant differences only between sex (Table 3).

Body and elytron length, length of the antennae and of the $2^{\text {nd }}$ and $3^{\text {rd }}$ antennal segments, maximum pronotum width and length of the median tibia and posterior tarsi were the traits showing significant differences between sexes (Table 3). Body and elytron length as well as length of the median tibia were longer for females, while length of antenna and of the $2^{\text {nd }}$ and $3^{\text {rd }}$ antennal segments, pronotum width and length of the posterior tarsi were longer in males (Table 4).

\section{Discussion}

The analysis of the 28 morphometric traits between sexes and seasons ( 0.05 at $5 \%$ ) showed no significance. On the other hand, among opposite sexes was significant and related to sexual dimorphism (0,007 to $5.0 \%)$. The females showed to be larger than males by their body and elytra length. In general the larger length of the females is associated with reproductive features (Renthal et al., 2003). The males present larger antenna which appear to support larger number of receptor sensila that increases, among other functions, its capacity to locate the females for mating (Chapman, 1998). Other characteristics found in the males were the largest width of the pronotum and posterior tarsi as well as the smaller length of the medium tibia. The meaning of these differences is not clear, but represent expressions of sexual dimorphism. Temperature was the only influence in the distribution of adults seasonal activity. The analysis between individuals of the same sex in different seasons showed no significance. The few individuals that appeared in the dry season appear to have had a delay in their development. This probable problem was not reflected in the 28 morphometric traits. The abundance of $O$. discicolle in the time of higher temperature or the wet season means the reproductive period of the species in the Atlantic forest is between October to March.

\section{References}

ANDERSON, R.S. 1982. The decreasing abundance of Nicrophorus americanus (Coleoptera: Silphidae) in eastern North America. Coleopt. Bull., 36(2):362-365.
CARVALHO, L.M.L. \& LINHARES, A.X. 2001. Seasonality of insect succession and pig carcass decomposition in southeastern Brazil. J. Forensic Sci., 46(3):604-608.

CATTS, E.P. \& HASKELL, N.H. 1990. Entomology \& Death: A Procedural Guide. Joyce's Print Shop, Inc., Clemson, South Carolina.

CHAPMAN, R.F. 1998. The insects: Structure and Function. 4 ed. Cambridge.

COSTA, C. 2000. Estado de Conocimiento de los Coleoptera Neotropicales. In: Fermín Martín-Piera; Juan José Morrone; Antonio Melic. (Org.). Hacia un Prouecto CYTED para el Inventario y estimación de la Diversidad Entomológica en Iberoamérica: PrIBES 2000. 1 ed. Zaragoza, v. 1, p. 1-326.

EMETS, U.M. \& ZHULIDOV,A.V. 1982. Geographic variality of the content of some chemical elements in the bodies of beetles (Coleoptera: Silphidae) of the genus Silpha. Ekologiya., 10(1):51-57.

FERREIRA, P.S.F. \& MARTINS, D.S. (1982) Contribuição ao método de captura de insetos por meio de armadilha luminosa, para obtenção de exemplares sem danos morfológicos. Ceres., 29(165):538-543.

KRYZHANOUSKII, O. \& SABIROBA L.O.R. 1981. Some species of Coleoptera new for fauna of Central Asia from Southwest Turkem SSR, USSR. Entomol. Obozr., 60(4):782-783.

OLIVEIRA-COSTA, J. 2003. Entomologia Forense. Quando os Insetos são Vestígios. Millenium, São Paulo.

PAYNE, J. A. \& CROSSLEY, D. A. 1966. Animal species associated with pig carrion. ORNL/TM-1432. $70 \mathrm{pp}$.

PECK, S.B. \& ANDERSON, R.S. 1982. The distribuition and biology of the Alpine Tundra carrion beetle of Thanatophilus coloradensis (Wickham) in North America (Coleoptera: Silphidae), Coleopt. Bull., 36(1):112-115.

PRINS, A.J. 1984. Morphological and biological notes on some South African arthropods associated with decaying organic matter 2. The predatory families Carabidae, Hydrophilidae, Histeridae, Staphylinidae and Silphidae (Coleoptera). Ann. S. Afr. Mus., 92(4):295-356

REED, HB, JR. 1958. A study of dog carcass communities in Tennessee, with special reference to the insects. Am. Midl. Nat., 59(1):213-245.

RENTHAL, R.; VELASQUEZ, D.; OLMOS, D.; HAMPTON, J. \& WERGIN, W.P. 2003. Structure and distribuition of antennal sensila of the red imported fire ant. Micron., 34(8):405-413.

SAS INSTITUTE. 2001: SAS User's Guide: Statistics, version 8.2. $6^{\text {th }}$ ed. SAS Institute, Cary, NC.

SCHAWALLER, W. (1977). Zwei neue Pteroloma-Arten aus dem Nepal- Himalaya, ergänzende Bemerkungen zu und Katalog der Pterolomini (Insecta: Coleoptera: Silphidae). - Senckenb. Biol., 58:171-184. 
WILSON, D.S. \& KNOLLENBERG, W.G. 1984. Food discrimination and ovarian development in burying beetles (Coleoptera: Silphidae: Nicrophorus). Ann. Entomol. Soc. Am., 77(2):165-170.

WILSON, DS, WG KNOLLENBERG, AND J. FUDGE. 1984. Species packing and temperature dependent competition among burying beetles (Silphidae, Nicrophorus). Ecol. Entomol., 9(2):205-216.

Title: Seasonal abundance and sexual variation in morphometric traits of Oxelytrum discicolle (Brulle, 1840) (Coleoptera: Silphidae) in a Brazilian Atlantic Forest.

Authors: Paulo Sérgio Fiuza Ferreira, Evaldo Martins Pires, Raul Narciso Carvalho Guedes, Márcio Mendes \& Lívia Aguiar Coelho

Biota Neotropica, Vol. 6 ( number 2): 2006

http://www.biotaneotropica.org.br/v6n2/pt/ abstract?article+bn02206022006

Date Received 08/01/2005 - Revised 02/28/2006

Accepted 05/11/2006

ISSN 1676-0611

http://www.biotaneotropica.org.br 
Table 1. Correlations between abundance of Oxelytrum discicolle and weather parameters.

\begin{tabular}{lll}
\hline Weather parameters & \multicolumn{2}{l}{ Total number of O. discicolle collected } \\
\cline { 2 - 3 } & $\mathrm{r}$ & $p$ \\
\hline Rainfall (mm) & 0.33 & 0.12 \\
Temperature $\left({ }^{\circ} \mathrm{C}\right)$ & 0.43 & $0.03^{*}$ \\
Relative humidity $(\%)$ & -0.20 & 0.25 \\
\hline
\end{tabular}

* Significant at $p<0.05$.

Table 2. Multivariate analysis of variance (MANOVA) for seasonal and sex differences in 28 morphometric traits of Oxelytrum discicolle

\begin{tabular}{llllll}
\hline Sources of variation & Wilks' lambda & $\mathrm{F}$ & $\mathrm{df}_{\text {numerator }}$ & $\mathrm{df}_{\text {denominator }}$ & $p$ \\
\hline - Season & & & & & \\
- Sex & 0.8617 & 1.50 & 28 & 262.00 & $0.05^{*}$ \\
- Season x Sex & 0.8092 & 2.21 & 28 & 262.00 & $0.007^{*}$ \\
\hline
\end{tabular}

* Significant at $5.0 \%$ probability.

Table 3. Univariate analysis of variance (ANOVA) for seasonal and sex differences in 28 morphometric traits of Oxelytrum discicolle $\left(d f_{\text {error }}=289\right)$

\begin{tabular}{|c|c|c|c|c|c|c|}
\hline \multirow[t]{3}{*}{ Morphometric trait } & \multicolumn{2}{|c|}{ Model } & \multicolumn{4}{|c|}{ Sources of Variation } \\
\hline & \multirow[t]{2}{*}{$\mathrm{F}$} & \multirow[t]{2}{*}{$\mathbf{p}$} & \multicolumn{2}{|c|}{ Season } & \multicolumn{2}{|l|}{ Sex } \\
\hline & & & $\mathrm{F}$ & $p$ & $\mathrm{~F}$ & $p$ \\
\hline Body length & 5.87 & $0.002 *$ & 0.11 & 0.73 & 11.65 & $0.003^{*}$ \\
\hline Body width & 1.25 & 0.29 & - & - & - & - \\
\hline Head length & 0.55 & 0.58 & - & - & - & - \\
\hline Head width & 0.16 & 0.95 & - & - & - & - \\
\hline Vertex width & 0.03 & 0.97 & - & - & - & - \\
\hline Distance between antennal base & 2.04 & 0.13 & - & - & - & - \\
\hline Length of the antennae & 8.54 & $0.001 *$ & 0.30 & 0.58 & 16.72 & $<0.001^{*}$ \\
\hline Length of the antennal club & 0.32 & 0.73 & - & - & - & - \\
\hline Length of $1^{\text {st }}$ antennal segment & 1.92 & 0.15 & - & - & - & - \\
\hline Length of $2^{\text {nd }}$ and $3^{\text {rd }}$ antennal segments & 4.56 & $0.011 *$ & 0.01 & 0.91 & 9.11 & $0.002 *$ \\
\hline Length of compound eye & 1.71 & 0.18 & - & - & - & - \\
\hline Width of compound eye & 1.53 & 0.21 & - & - & - & - \\
\hline Width of the pronotum base & 1.46 & 0.23 & - & - & - & - \\
\hline Median pronotum length & 1.24 & 0.29 & - & - & - & - \\
\hline Maximum pronotum width & 5.27 & $0.005 *$ & 0.75 & 0.39 & 9.25 & $0.002 *$ \\
\hline Escutellum length & 1.79 & 0.17 & - & - & - & - \\
\hline Width of the escutellum base & 0.30 & 0.74 & - & - & - & - \\
\hline Elytron length & 14.68 & $<0.001^{*}$ & 0.05 & 0.82 & 29.34 & $<0.001^{*}$ \\
\hline Maximum elytron width & 1.31 & 0.27 & - & - & - & - \\
\hline Length of the anterior femur & 2.10 & 0.12 & - & - & - & - \\
\hline Length of the anterior tibia & 2.51 & 0.08 & - & - & - & - \\
\hline Length of the anterior tarsi & 0.71 & 0.49 & - & - & - & - \\
\hline Length of the median femur & 0.10 & 0.91 & - & - & - & - \\
\hline Length of the median tibia & 2.82 & $0.05 *$ & 0.57 & 0.45 & 5.02 & $0.03 *$ \\
\hline Length of the median tarsi & 1.08 & 0.34 & - & - & - & - \\
\hline Length of the posterior femur & 0.47 & 0.63 & - & - & - & - \\
\hline Length of the posterior tibia & 1.41 & 0.25 & - & - & - & - \\
\hline Length of the posterior tarsi & 6.54 & $0.002 *$ & 0.28 & 0.59 & 12.13 & $0.001^{*}$ \\
\hline
\end{tabular}

* Significant at 5.0\% probability. 
Table 4. Morphometric differences $(\mathrm{mm})( \pm \mathrm{SE}$ ) between males and females of Oxelytrum discicolle. Means followed by the same letter in a row are not significantly different at $\mathrm{p}<0.05$ by the $F$ test.

\begin{tabular}{lll}
\hline Morphometric trait & Sex \\
\cline { 2 - 3 } & Female & Male \\
\hline Body length & $23.29 \pm 0.18 \mathrm{a}$ & $22.40 \pm 0.22 \mathrm{~b}$ \\
Length of the antennae & $5.51 \pm 0.07 \mathrm{~b}$ & $5.81 \pm 0.07 \mathrm{a}$ \\
${\text { Length of } 2^{\text {nd }} \text { and } 3^{\text {rd }} \text { antennal segments }}_{\text {Maximum pronotum width }}^{1.05 \pm 0.01 \mathrm{~b}}$ & $1.09 \pm 0.01 \mathrm{a}$ \\
Elytron length & $7.66 \pm 0.07 \mathrm{~b}$ & $7.99 \pm 0.08 \mathrm{a}$ \\
Length of the median tibia & $15.80 \pm 0.13 \mathrm{a}$ & $14.71 \pm 0.15 \mathrm{~b}$ \\
Length of the posterior tarsi & $5.32 \pm 0.05 \mathrm{a}$ & $5.16 \pm 0.06 \mathrm{~b}$ \\
\hline
\end{tabular}

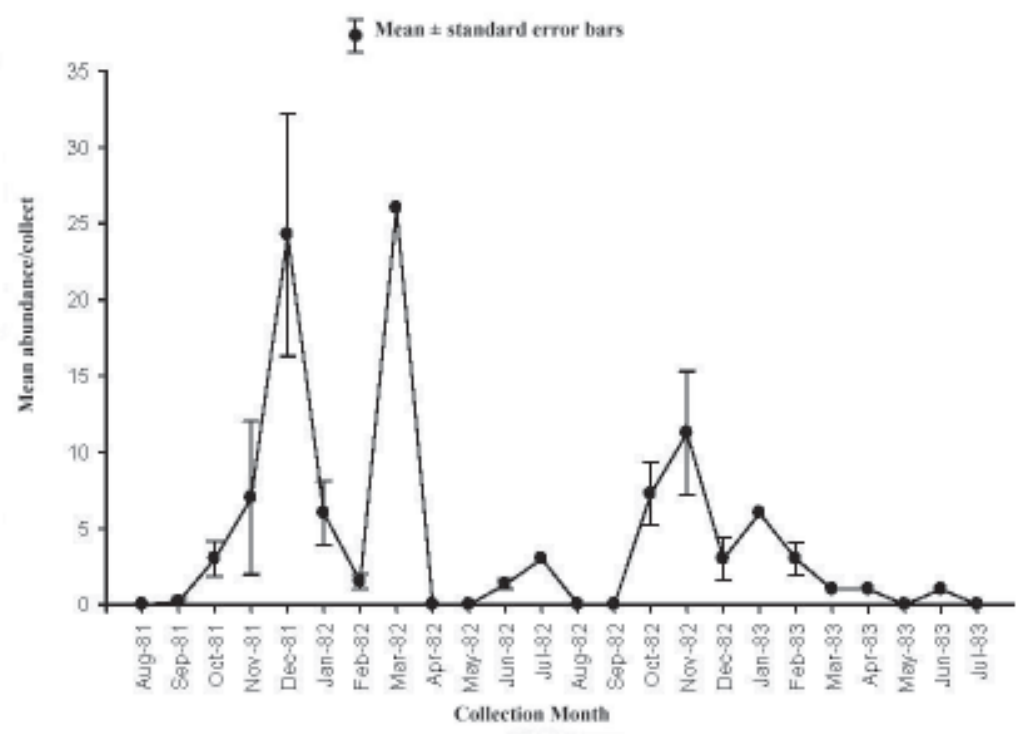

Figure 1 - The seasonal occurrence of 293 specimens of Oxelytrum discicolle throughout the sampling period (August 1981 to July 1983). The weekly samples results were combined to a monthly total as a single number. 


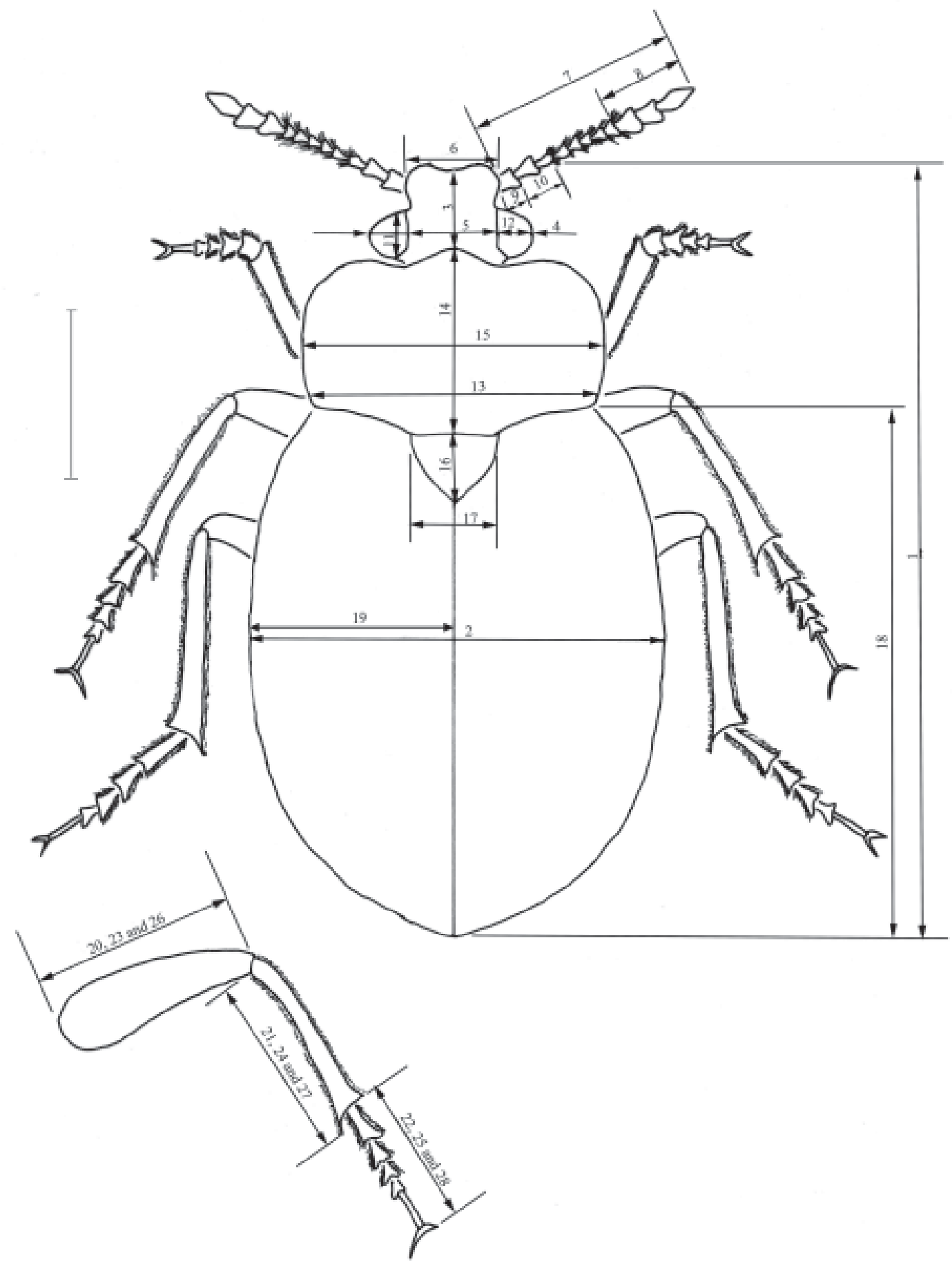

Figure 2 - Measurements of morphometric traits in Oxelytrum discicolle (Brulle, 1840). Scale (5 mm).

1 - body length (= Ó head length, with length of the pronotum and elytron length); 2 - maximum body width; 3 - head length; 4 - head width; 5 - frons width; 6 - distance between antennal insection; 7 - length of the antennae; 8 - length of the antennal club; 9 - length of scape; 10 - length of $2^{\text {nd }}$ and $3^{\text {rd }}$ antennal segments; 11 - length of compound eye; 12 - width of compound eye; 13 - width of the pronotum base; 14 median pronotum length; 15 - maximum pronotum width; 16 - scutellum length; 17 - width of the scutellum base; 18 - elytron length; 19 maximum elytron width; 20 - length of the anterior femur; 21 - length of the anterior tibia; 22 - length of the anterior tarsi; 23 - length of the median femur; 24 - length of the median tibia; 25 - length of the median tarsi; 26 - length of the posterior femur; 27 - length of the posterior tibia; 28 - length of the posterior tarsi.

http://www.biotaneotropica.org.br 